\title{
Effect of synthesis conditions on electrical and catalytical properties of a perovskite with high value of A-site cation size mismatch
}

\author{
K. Vidal ${ }^{a, *}$, A. Larrañaga ${ }^{a}$, A. Morán ${ }^{a}$, A.T. Aguayo ${ }^{a}$, M.A. Laguna-Bercero ${ }^{b}$, M.P. \\ Yeste $^{c}$, J.J. Calvinoc ${ }^{c}$ and M.I. Arriortua ${ }^{a, *}$
}

anniversidad del País Vasco (UPV/EHU), Facultad de Ciencia y Tecnología, Barrio Sarriena S/N, 48940 Leioa, Vizcaya, Spain

${ }^{\mathrm{b}}$ CSIC-Universidad de Zaragoza, Instituto de Ciencia de Materiales de Aragón (ICMA), Pedro Cerbuna 12, 50009 Zaragoza, Spain

'Universidad de Cádiz, Departamento de Ciencia de los Materiales e Ingeniería Metalúrgica y Química Inorgánica, Facultad de Ciencias, Campus Río San Pedro, E11510 Puerto Real (Cádiz), Spain

\begin{abstract}
:
The perovskite $\mathrm{La}_{0.15} \mathrm{Sm}_{0.35} \mathrm{Sr}_{0.08} \mathrm{Ba}_{0.42} \mathrm{FeO}_{3-\delta}$ has been prepared by the glycine nitrate route, varying the calcination temperature, fuel/oxidizer ratio and cooling rate, in order to study the sample preparation influence on the properties in the context of their application as a electrode material for SOFCs. The obtained materials have been characterized by X-ray diffraction, scanning electron microscopy, electrical and BET surface area measurements, and also the reaction between oxygen and CO, which can occur in the SOFC for the conversion of chemical energy into electrical energy. All samples present phase segregation showing two perovskite with rhombohedral crystal structure. SEM images show a well-necked morphology of the powders which are composed of nanosized particles and agglomerations of grains. The BET specific
\end{abstract}


surface area of the samples decreases as calcination temperature increases, as well as for the quenched sample. The measured electronic conductivity values $(<50 \mathrm{~S} / \mathrm{cm})$ are characteristic for samples with these high values of $\sigma^{2}\left(\mathrm{r}_{\mathrm{A}}\right)$. The catalytic activity tests for the $\mathrm{CO}$ oxidation reaction showed a $\mathrm{T} 50 \%$ value about $440^{\circ} \mathrm{C}-450^{\circ} \mathrm{C}$, $\mathrm{CO}$ conversion reaching $100 \%$ at approximately $600^{\circ} \mathrm{C}$ for all the prepared perovskites. Then, for the $\mathrm{La}_{0,15} \mathrm{Sm}_{0,35} \mathrm{Sr}_{0,08} \mathrm{Ba}_{0,42} \mathrm{FeO}_{3-\delta}$ perovskite, $\mathrm{CO}$ conversion temperature is lower than usual SOFCs operating temperature. This points out to the technological interest of these materials in the framework of reducing the operating temperature of SOFCs.

Keywords: Chemical Synthesis; Electrical Conductivity; Cathode Material; Perovskite Phases; SOFC.

* Corresponding Author: Karmele Vidal and María Isabel Arriortua e-mail: karmele.vidal@ehu.es and maribel.arriortua@ehu.es Phone number: 946015984; Fax number: 946013500. 


\section{Introduction}

Perovskite systems such as $\mathrm{La}_{1-\mathrm{x}} \mathrm{Sr}_{x} \mathrm{FeO}_{3-\delta}$ (LSF) are receiving researcher's attention for their interesting applications such as ceramic membranes (CMs) for oxygen separation, solid oxide fuel cells (SOFCs) electrodes for efficient power generation and catalysts for complete oxidation of CO [1-3]. Catalytic CO oxidation is a model gassolid reaction that has been extensively studied because of its applications in many fields such as air purification, pollution control or fuel cell technologies [4-6]. With regard to SOFCs, the major species involved in the reaction at the anode are likely related to $\mathrm{H}_{2}$ and $\mathrm{CO}$ electro-oxidation [7].

It is well known that the fabrication route plays a critical role on the physical and chemical properties of the reaction products, controlling the structure, morphology, grain size and surface area of the obtained materials. Surface area is a crucial issue to be considered for perovskite oxides applications, as they normally have low surface area because of the high temperatures and long calcination time used in the preparation process, which would limit their catalytic activity and performance of electrochemical cells. Furthermore, the surface area could also affect some physicochemical properties of these material such as their reducibility or their oxygen vacancy contents [8,9].

In order to develop these advanced materials, combustion methods have been proposed as one of the most promising procedures for their synthesis [10,11]. This method consists of a highly exothermic self-combustion reaction between the fuel (usually glycine, urea or alanine) and the oxidant (metal nitrates), that produces enough heat to obtain the ceramic powders. The characteristics (including purity, structure and size) of the combustion synthesis oxide powders are typically determined by several synthetic parameters, such as the species of fuel and oxidizer reactants, the fuel/oxidizer ratio, and the subsequent sintering treatment after the combustion process [12]. 
On the other hand, physical properties of these perovskite materials are very sensitive to changes in the doping level $(\mathrm{x})$, the average size of the A cations $\left(<\mathrm{r}_{\mathrm{A}}>\right)$, and the effects of A cation size disorder $\left(\sigma^{2}\left(r_{A}\right)\right)$ quantified as $\left.\sigma^{2}\left(r_{A}\right)=\left\langle r_{A}{ }^{2}\right\rangle-<r_{A}\right\rangle^{2}[13]$.

Our research approach to find the optimum synthetic conditions for new materials within the LSF system has been based on the study of only one of the indicated parameters isolated from the rest. In this sense, our group [14,15] has evaluated from impedance spectroscopy analysis the effect of the A-cation site disorder on the electrochemical properties of $\mathrm{La}_{1-\mathrm{x}} \mathrm{Sm}_{\mathrm{x}} \mathrm{Sr}_{1-\mathrm{y}} \mathrm{Ba}_{\mathrm{y}} \mathrm{FeO}_{3-\delta}$ perovskites, whilst $\mathrm{x}$ and $<\mathrm{r}_{\mathrm{A}}>$ are fixed to 0.5 and $\sim 1.30 \AA$, respectively, for their application as SOFC cathodes. Although the effect of $\sigma^{2}\left(\mathrm{r}_{\mathrm{A}}\right)$ was clear at $\mathrm{OCV}$ at 800 and $700^{\circ} \mathrm{C}$ (polarisation value, Rp, higher as $\sigma^{2}\left(r_{A}\right)$ increased), its effects were highly attenuated when a current was applied (100 and $300 \mathrm{~mA}$ ), the Rp being lower for the sample with larger value of $\sigma^{2}\left(\mathrm{r}_{\mathrm{A}}\right)$ under 300 $\mathrm{mA}$ and at $700^{\circ} \mathrm{C}$.

Considering these results, this work is focused on the synthesis of compositions with higher values of $\mathrm{A}$ cation size disorder $\left(\mathrm{La}_{0.15} \mathrm{Sm}_{0.35} \mathrm{Sr}_{0.08} \mathrm{Ba}_{0.42} \mathrm{FeO}_{3-\delta}\right)$ varying the calcinations temperature, fuel/oxidizer ratio and cooling rate. These compounds have been characterized by X-ray powder diffraction (XRD), scanning electron microscopy (SEM), BET surface area, electrical measurements and catalytic CO oxidation tests.

\section{Experimental}

\subsection{Powder preparation}

$\mathrm{La}_{0.15} \mathrm{Sm}_{0.35} \mathrm{Sr}_{0.08} \mathrm{Ba}_{0.42} \mathrm{FeO}_{3-\delta}$ samples were prepared by the glycine nitrate combustion (GNC) process, a self-combustion technique that uses glycine as fuel and nitrates of the metal components as oxidants. 
These metal nitrates $\left(\mathrm{La}\left(\mathrm{NO}_{3}\right)_{3} .6 \mathrm{H}_{2} \mathrm{O}(>99 \%), \mathrm{Sm}\left(\mathrm{NO}_{3}\right)_{3} \cdot 6 \mathrm{H}_{2} \mathrm{O}(>99 \%), \operatorname{Sr}\left(\mathrm{NO}_{3}\right)_{2}\right.$. (>99.99\%), $\mathrm{Ba}\left(\mathrm{NO}_{3}\right)_{2}(>99.995 \%)$, and $\mathrm{Fe}\left(\mathrm{NO}_{3}\right)_{2} .9 \mathrm{H}_{2} \mathrm{O}$ (98.5\%), all from Aldrich) were dissolved in distilled water. The solutions (dissolved metal nitrates) were mixed in a glass beaker, which was placed on a hot plate, under constant stirring, to evaporate excess water. The synthesis was carried out varying the calcination temperature (1000, 1050 and $1100^{\circ} \mathrm{C}$ ), fuel/oxidizer ratio (G/N = 1 and 2) and cooling rate (slow cooling and air-quenched). The resulting viscous liquid started autoignition just after placing the glass beaker directly onto a preheated plate (at $450^{\circ} \mathrm{C}$ ). The resulting powders were pelletized and calcined in air between 850 and $1100^{\circ} \mathrm{C}$ for 10 hours to obtain pure samples.

\subsection{Characterization techniques}

The structural analysis was performed using X-ray diffraction (XRD). XRD data were collected on a Bruker D8 Advance diffractometer equipped with a Cu tube, a Ge (111) incident beam monochromator $(\lambda=1.5406 \AA)$ and a Sol-X energy dispersive detector. Data were collected from 18 to $110^{\circ}, 2 \theta$, (step size $=0.02^{\circ}$ and time per step $=10$ s) at room temperature (r.t.). All samples were single phase without detectable impurities. The crystal structure was refined by the Rietveld method [16] using the GSAS software package [17].

Compositional analysis was performed on all prepared samples to confirm that the expected elemental composition was achieved. All metal contents were determined by inductively coupled plasma atomic emission spectroscopy (ICP-AES) on a Horiba Yobin Yvon Activa spectrophotometer.

Brunauer-Emmetty-Teller (BET) [18] surface areas were determined by nitrogen adsorption-desorption in a MICROMERITICS ASAP 2010 equipment. 
Morphologies of the powder samples and the sintered pellets were observed using a scanning electron microscope (JEOL JSM-7000F). Secondary electron images were taken at $20 \mathrm{kV}$ and $1 \cdot 1 \cdot 10^{-11} \mathrm{~A}$.

For bulk conductivity and thermal expansion (TEC) measurements, powders were pelletised and sintered at $1250^{\circ} \mathrm{C}$, and subsequently, cut into bars. The bulk density of each sample was estimated by measuring the mass and the dimensions of the bars. All samples had a relative density around $85 \%$ of the theoretical (X-ray) density.

DC conductivity measurements were performed in air by the four-point DC method using a VSP potenciostat controlled by PC using Lab Windows/CVI field point system. Electrical contacts were made using Pt wires and Pt paste placed over whole end faces ensuring a homogeneous current flow. Voltage contacts were made as small as possible to avoid any disturbance of the contacts on the current flow. Measurements were performed from 300 to $800^{\circ} \mathrm{C}$. The conductivity $(\sigma)$ was determined from a set of $\mathrm{V}-\mathrm{I}$ values by taking $\sigma=1 / \rho=\mathrm{L} / \mathrm{A} \times \mathrm{dI} / \mathrm{dV}$, where $\mathrm{L}$ is the distance between voltage contacts and A is the sample cross section.

The catalytic activity of the samples was evaluated in the CO oxidation reaction. The experiments were carried out with $0.25 \mathrm{~g}$ of perovskite power diluted with quartz sand (0.1g). Prior to reaction, the samples were cleaned to remove water and carbonates from the surface. For this purpose, each sample was heated from room temperature up to $200^{\circ} \mathrm{C}\left(10^{\circ} \mathrm{C} \cdot \mathrm{min}^{-1}\right)$ under a flow of $5 \% \mathrm{O}_{2} / \mathrm{He}$, kept at $200^{\circ} \mathrm{C}$ for $1 \mathrm{~h}$ and then cooled down to $150^{\circ} \mathrm{C}$. At this temperature the atmosphere was changed to pure $\mathrm{He}$ (15 $\left.\mathrm{min}\right)$ to remove the oxygen adsorbed on the surface, and then it was finally cooled down to room temperature. After that, the $\mathrm{CO}+\mathrm{O}_{2}$ reaction mixture $\left(1 \% \mathrm{CO}\right.$ and $0.6 \% \mathrm{O}_{2}$ balanced by $\mathrm{He}$ ) was passed through the reactor (30 min) before recording catalytic activity measurements for complete CO oxidation. Light-off curves were performed 
from room temperature up to $700^{\circ} \mathrm{C}$ at a heating rate of $10^{\circ} \mathrm{C} \cdot \mathrm{min}^{-1}$. The total feed rate of the reaction mixture was $100 \mathrm{~cm}^{3} \cdot \mathrm{min}^{-1}$. The gases at the outlet of the reactor were analysed with a Pfeiffer Prisma Mass Spectrometer.

\section{Results and discussion}

\subsection{Structural Study}

X-ray diffraction data collected for $\mathrm{La}_{0.15} \mathrm{Sm}_{0.35} \mathrm{Sr}_{0.08} \mathrm{Ba}_{0.42} \mathrm{FeO}_{3-\delta}$ samples obtained without impurities after the different synthetic conditions are shown in Fig. 1.

Figure 1

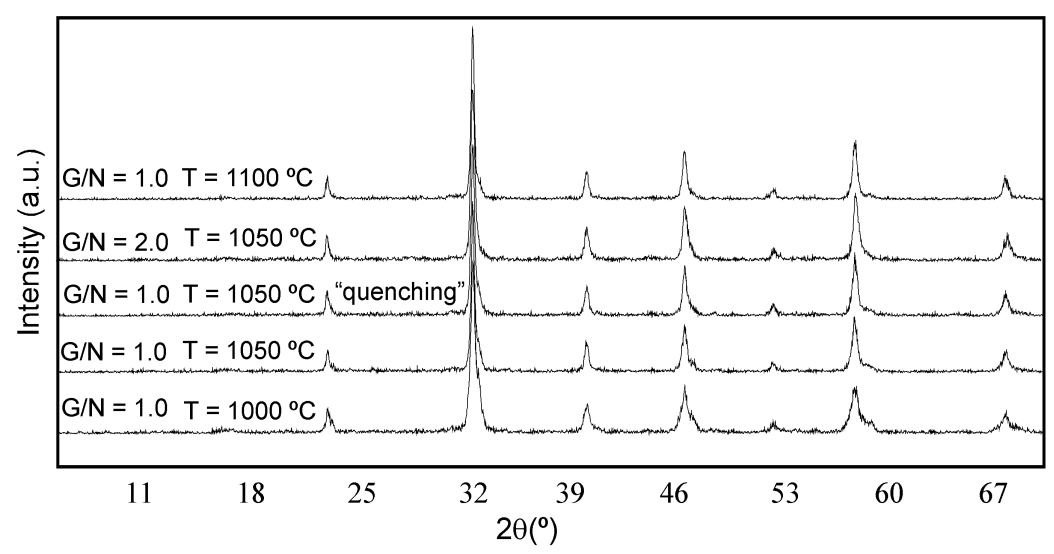

Fig. 1. X-ray diffraction patterns for $\mathrm{La}_{0.15} \mathrm{Sm}_{0.35} \mathrm{Sr}_{0.08} \mathrm{Ba}_{0.42} \mathrm{FeO}_{3-\delta}$ perovskites sintered by glycine nitrate combustion method at different synthetic conditions.

As expected, there is a remarkable dependence of phase constitution on temperature treatments for the combustion products, being the sample prepared at higher temperature the best crystallized, as compared with the other compounds.

Results from chemical analyses are presented in Tables 1 and 2, showing a good agreement between the analysed chemical compositions of the prepared powders and the nominal compositions. 


\section{Table 1}

Table 2

Table 1. Summary of the ICP analyses for the obtained perovskites with $\mathrm{La}_{0.15} \mathrm{Sm}_{0.35} \mathrm{Sr}_{0.08} \mathrm{Ba}_{0.42} \mathrm{FeO}_{3-\delta}$ nominal composition.

\begin{tabular}{c|c|c}
\hline Tsynthesis $\left({ }^{\circ} \mathrm{C}\right)$ & $\mathrm{G} / \mathrm{N}$ & Experimental composition \\
\hline 1000 & 1 & $\mathrm{La}_{0.13(2)} \mathrm{Sm}_{0.32(2)} \mathrm{Sr}_{0.08(1)} \mathrm{Ba}_{0.43(2)} \mathrm{Fe}_{1.00(3)}$ \\
\hline 1050 & 1 & $\mathrm{La}_{0.15(1)} \mathrm{Sm}_{0.33(2)} \mathrm{Sr}_{0.08(2)} \mathrm{Ba}_{0.44(2)} \mathrm{Fe}_{1.00(3)}$ \\
\hline 1050 with quenching & 1 & $\mathrm{La}_{0.14(1)} \mathrm{Sm}_{0.33(2)} \mathrm{Sr}_{0.08(2)} \mathrm{Ba}_{0.44(2)} \mathrm{Fe}_{1.00(3)}$ \\
\hline 1050 & 2 & $\mathrm{La}_{0.14(2)} \mathrm{Sm}_{0.32(2)} \mathrm{Sr}_{0.07(2)} \mathrm{Ba}_{0.40(2)} \mathrm{Fe}_{1.00(3)}$ \\
\hline 1100 & 1 & $\mathrm{La}_{0.13(2)} \mathrm{Sm}_{0.33(2)} \mathrm{Sr}_{0.08(2)} \mathrm{Ba}_{0.43(1)} \mathrm{Fe}_{1.00(3)}$ \\
\hline
\end{tabular}

Table 2. Summary of the ICP analyses for the obtained perovskites with $\mathrm{La}_{0.15} \mathrm{Sm}_{0.35} \mathrm{Sr}_{0.08} \mathrm{Ba}_{0.42} \mathrm{FeO}_{3-\delta}$ nominal composition and sintered at $1250^{\circ} \mathrm{C}$.

\begin{tabular}{c|c|c}
\hline Tsynthesis $\left({ }^{\circ} \mathrm{C}\right)$ & $\mathrm{G} / \mathrm{N}$ & Experimental composition \\
\hline 1050 & 1 & $\mathrm{La}_{0.12(1)} \mathrm{Sm}_{0.30(2)} \mathrm{Sr}_{0.07(2)} \mathrm{Ba}_{0.44(2)} \mathrm{Fe}_{1.00(3)}$ \\
\hline 1050 with quenching & 1 & $\mathrm{La}_{0.12(1)} \mathrm{Sm}_{0.30(2)} \mathrm{Sr}_{0.07(2)} \mathrm{Ba}_{0.42(2)} \mathrm{Fe}_{1.00(3)}$ \\
\hline 1050 & 2 & $\mathrm{La}_{0.15(2)} \mathrm{Sm}_{0.34(2)} \mathrm{Sr}_{0.07(2)} \mathrm{Ba}_{0.41(2)} \mathrm{Fe}_{1.00(3)}$ \\
\hline
\end{tabular}

Fig. 2 shows the Rietveld refinement of XRD data for the samples. Analysis of the X-ray diffraction (XRD) data for the different samples indicated that all of them crystallized as two different compositions, both in the rhombohedral space group R-3c, being the observed phase segregation smaller with increasing calcination temperature.

Figure 2 

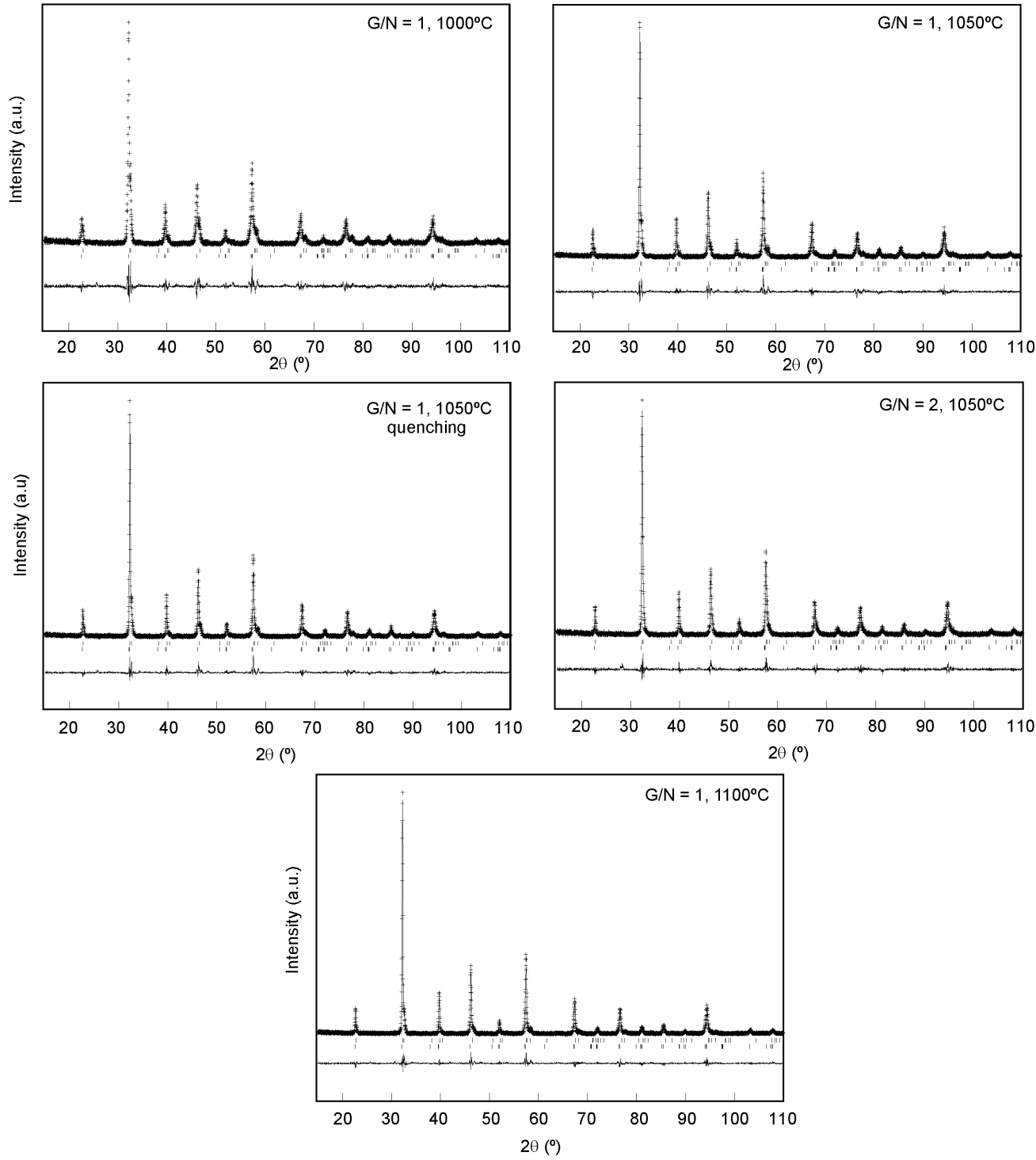

Fig. 2. Rietveld fits of the XRD data for $\mathrm{La}_{0.15} \mathrm{Sm}_{0.35} \mathrm{Sr}_{0.08} \mathrm{Ba}_{0.42} \mathrm{FeO}_{3-\delta}$ perovskites using rhombohedral R-3c space group.

Final refined values of the structural parameters for the compounds obtained at 1000 , 1050 and $1100^{\circ} \mathrm{C}$, respectively, are summarised in Table 3.

Table 3 
Table 3. Structural parameters obtained by Rietveld refinement for $\mathrm{ABO}_{3}\left(\mathrm{~A}=\mathrm{La}_{0.15} \mathrm{Sm}_{0.35} \mathrm{Sr}_{0.08} \mathrm{Ba}_{0.42}\right.$; $\mathrm{B}=$ $\mathrm{Fe}$ ) perovskites sintered by glycine nitrate combustion method with $\mathrm{G} / \mathrm{N}=1$ at different temperature conditions.

\begin{tabular}{|c|c|c|c|c|c|c|}
\hline $\begin{array}{c}\text { Tcalcination }\left({ }^{\circ} \mathrm{C}\right) \\
\text { Symmetry }\end{array}$ & \multicolumn{2}{|c|}{$\begin{array}{c}1000 \\
\text { Rhombohedral }\end{array}$} & \multicolumn{2}{|c|}{$\begin{array}{c}1050 \\
\text { Rhombohedral }\end{array}$} & \multicolumn{2}{|c|}{$\begin{array}{c}1100 \\
\text { Rhombohedral }\end{array}$} \\
\hline Space group & $R \overline{3}_{c}$ & $R \overline{3} c$ & $R \overline{3} c$ & $R \overline{3} c$ & $R \overline{3} c$ & $R \overline{3} c$ \\
\hline w.t. Frac. & 0.75 & 0.25 & 0.76 & 0.24 & 0.80 & 0.20 \\
\hline $\mathrm{a}(\AA)$ & $5.559(1)$ & $5.515(1)$ & $5.558(1)$ & $5.544(2)$ & $5.558(1)$ & $5.550(2)$ \\
\hline$c(\AA)$ & 13.671(3) & $13.406(3)$ & $13.656(2)$ & 13.392(3) & $13.639(2)$ & 13.393(3) \\
\hline $\mathrm{V} / \mathrm{Z}\left(\AA^{3}\right)$ & $365.8(1)$ & 353.2(1) & $365.3(1)$ & $356.5(2)$ & $364.9(1)$ & $357.3(2)$ \\
\hline$\rho_{\text {the. }}\left(\mathrm{g} / \mathrm{cm}^{3}\right)^{*}$ & 6.591 & 6.827 & 6.600 & 6.763 & 6.608 & 6.749 \\
\hline Uiso(A) $_{(A)}$ & $1.63(4)$ & $2.21(4)$ & $1.34(3)$ & 1.92(3) & $1.89(3)$ & $2.46(3)$ \\
\hline Uiso(B) $_{(B)}$ & $0.94(4)$ & $1.43(4)$ & $0.95(3)$ & 1.44(3) & $1.08(3)$ & $1.57(3)$ \\
\hline $\mathrm{Ox}$ & $0.469(3)$ & $0.567(3)$ & $0.482(4)$ & $0.580(4)$ & $0.483(3)$ & $0.581(3)$ \\
\hline Uiso(O) $_{(0)}$ & $1.60(4)$ & $2.13(4)$ & $1.54(3)$ & 2.07(3) & $1.63(3)$ & $2.15(3)$ \\
\hline A-B (x2) $(\AA)$ & $3.418(1)$ & 3.351(1) & $3.414(1)$ & $3.348(1)$ & $3.410(1)$ & 3.348(1) \\
\hline A-B (x6) ( $(̊)$ & $3.405(1)$ & $3.375(1)$ & $3.405(1)$ & $3.390(1)$ & $3.404(1)$ & 3.393(1) \\
\hline$<\mathrm{A}-\mathrm{B}>(\AA)$ & $3.409(1)$ & 3.369(1) & $3.407(1)$ & 3.379(1) & $3.406(1)$ & 3.382(1) \\
\hline A-O (x3) $(\AA)$ & $2.949(2)$ & $3.129(2)$ & $2.876(3)$ & $3.217(3)$ & $2.872(2)$ & $3.224(2)$ \\
\hline A-O (x3) $(\AA)$ & $2.610(2)$ & $2.386(2)$ & $2.682(3)$ & $2.327(3)$ & $2.686(2)$ & $2.326(2)$ \\
\hline A-O (x6) $(\AA)$ & $2.792(1)$ & $2.769(1)$ & $2.786(1)$ & $2.782(1)$ & 2.784(1) & $2.784(1)$ \\
\hline$<\mathrm{A}-\mathrm{O}>$ & 2.786(1) & $2.763(1)$ & $2.783(2)$ & $2.777(2)$ & 2.781(1) & $2.779(1)$ \\
\hline B-O (x6) $(\AA)$ & $1.975(1)$ & $1.980(4)$ & $1.969(1)$ & $2.001(4)$ & $1.968(1)$ & $2.004(5)$ \\
\hline B-O-B $\left({ }^{\circ}\right)$ & $170.2(1)$ & $158.4(1)$ & 174.3(1) & $154.3(1)$ & $174.6(1)$ & 154.1(1) \\
\hline$\chi^{2}$ & \multicolumn{2}{|c|}{1.63} & \multicolumn{2}{|c|}{1.60} & \multicolumn{2}{|c|}{1.53} \\
\hline
\end{tabular}

${ }^{*}$ Assuming stoichiometric oxygen content.

A slight increase in cell volume, the average Fe-O, Fe-A and A-O bond distances and Fe-O-Fe angles is observed with increasing calcination temperature. This expansion phenomenon could be explained by the greater loss of oxygen at higher calcination temperatures, which leads to ascending repulsion force between neighbouring cations $[19,20]$ and/or to the formation of bigger cation, $\mathrm{Fe}^{3+}\left(\mathrm{rFe}^{3+}(\mathrm{VI})=0.645 \AA\right.$; $\mathrm{rFe}^{4+}(\mathrm{VI})=$ $0.585 \AA)[21]$.

On the other hand, the final refined values of the structural parameters for the perovskites obtained at $1050^{\circ} \mathrm{C}$ under different preparation conditions are summarised in Table 4.

Table 4 
Table 4. Structural parameters obtained by Rietveld refinement for $\mathrm{ABO}_{3}\left(\mathrm{~A}=\mathrm{La}_{0.15} \mathrm{Sm}_{0.35} \mathrm{Sr}_{0.08} \mathrm{Ba}_{0.42} ; \mathrm{B}=\right.$ $\mathrm{Fe})$ perovskites sintered by glycine nitrate combustion method at $1050^{\circ} \mathrm{C}$ using different conditions.

\begin{tabular}{|c|c|c|c|c|c|c|}
\hline $\begin{array}{c}\text { Tcalcination }\left({ }^{\circ} \mathrm{C}\right) \\
\text { Symmetry }\end{array}$ & \multicolumn{2}{|c|}{$\begin{array}{c}\mathrm{G} / \mathrm{N}=1 \\
\text { Rhombohedral }\end{array}$} & \multicolumn{2}{|c|}{$\begin{array}{c}\text { G/N = 1, quenching } \\
\text { Rhombohedral }\end{array}$} & \multicolumn{2}{|c|}{$\mathrm{G} / \mathrm{N}=2$} \\
\hline Space group & $R \overline{3}_{c}$ & $R \overline{3}_{C}$ & $R \overline{3}_{c}$ & $R \overline{3} c$ & $R \overline{3}_{c}$ & $R \overline{3} c$ \\
\hline w.t. Frac. & 0.76 & 0.24 & 0.79 & 0.21 & 0.72 & 0.28 \\
\hline $\mathrm{a}(\AA)$ & $5.558(1)$ & $5.544(2)$ & $5.564(1)$ & $5.560(1)$ & $5.550(1)$ & $5.526(2)$ \\
\hline$c(\AA)$ & $13.656(2)$ & 13.392(3) & $13.595(1)$ & 13.395(1) & $13.581(4)$ & $13.453(3)$ \\
\hline $\mathrm{V} / \mathrm{Z}\left(\AA^{3}\right)$ & 365.3(1) & $356.5(2)$ & $364.5(1)$ & $358.6(1)$ & 362.3(1) & $355.8(2)$ \\
\hline$\rho_{\text {the. }}\left(\mathrm{g} / \mathrm{cm}^{3}\right)^{*}$ & 6.600 & 6.763 & 6.615 & 6.723 & 6.656 & 6.777 \\
\hline Uiso $_{(\mathrm{A})}$ & 1.34(3) & $1.92(3)$ & $2.46(3)$ & $2.11(3)$ & $0.84(3)$ & $1.42(4)$ \\
\hline $\operatorname{Uiso}_{(\mathrm{B})}$ & $0.95(3)$ & $1.44(3)$ & $1.15(3)$ & $1.39(3)$ & $0.96(3)$ & $1.45(4)$ \\
\hline $\mathrm{Ox}$ & $0.482(4)$ & $0.580(4)$ & $0.484(3)$ & $0.582(3)$ & $0.468(4)$ & $0.566(4)$ \\
\hline $\operatorname{UisO}_{(\mathrm{O})}$ & $1.54(3)$ & $2.07(3)$ & $1.60(3)$ & $2.13(3)$ & $1.85(3)$ & $2.37(4)$ \\
\hline A-B (x2) (Å) & $3.414(1)$ & 3.348(1) & 3.399(1) & 3.349(1) & 3.395(1) & 3.363(1) \\
\hline A-B (x6) (Å) & $3.405(1)$ & 3.390(1) & $3.406(1)$ & 3.399(1) & 3.398(1) & 3.382(1) \\
\hline$<\mathrm{A}-\mathrm{B}>(\AA)$ & $3.407(1)$ & 3.379(1) & $3.404(1)$ & 3.386(1) & 3.397(1) & 3.377(1) \\
\hline A-O (x3) (A) & $2.876(3)$ & $3.217(3)$ & $2.694(2)$ & $3.236(2)$ & $2.600(2)$ & $3.129(2)$ \\
\hline A-O (x3) ( $\AA)$ & 2.682(3) & 2.327(3) & $2.870(2)$ & $2.325(2)$ & $2.950(2)$ & 2.397(2) \\
\hline 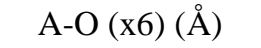 & $2.786(1)$ & $2.782(1)$ & $2.779(1)$ & $2.787(1)$ & $2.779(1)$ & $2.776(1)$ \\
\hline$<\mathrm{A}-\mathrm{O}>$ & $2.783(2)$ & $2.777(2)$ & $2.780(1)$ & $2.784(1)$ & $2.777(1)$ & 2.769(1) \\
\hline B-O (x6) ( $\AA)$ & 1.969(1) & $2.001(4)$ & $1.968(1)$ & $2.007(4)$ & $1.969(1)$ & $1.984(4)$ \\
\hline $\mathrm{B}-\mathrm{O}-\mathrm{B}\left({ }^{\circ}\right)$ & 174.3(1) & 154.3(1) & $174.9(1)$ & 153.8(1) & 169.8(1) & 158.7(1) \\
\hline$\chi^{2}$ & \multicolumn{2}{|c|}{1.60} & \multicolumn{2}{|c|}{1.59} & \multicolumn{2}{|c|}{1.38} \\
\hline
\end{tabular}

${ }^{*}$ Assuming stoichiometric oxygen content.

As observed, for the samples with $\mathrm{G} / \mathrm{N}=1$, there is a slight increase in structural parameters for the quenched sample as compared to the slowly cooled sample. X-D. Zhou [22] and L.Ge et.al [23] observed that a fast cooling of the powder sample leads to an increase of the mole ratio of $\mathrm{Fe}^{3+}$ (increase in cation size due to the reduction of $\mathrm{Fe}$ ions from a high valence state to a lower valence state) and oxygen vacancies (repulsive force arising between those mutually exposed cations when oxygen ions are absent in the lattice). This is due to there is not enough time for all oxygen vacancies to be filled and therefore, the iron cation was mostly kept in a lower valance state $\left(\mathrm{Fe}^{3+}\right)$. The Fe-OFe bond angle increases as calcination temperature increases, as well asfor the quenched sample, as a result of the presence of oxygen vacancies that can relax the strain in the structure and reduce this distortion. 
This decrease in structural parameters is higher with increasing the G/N molar ratio from 1 to 2. According to other reported works [24,25], by increasing the fuel/oxidant ratio, the perovskite structure changes to a less symmetric structure. In this case, the variation observed seems to be due to a small change in mean ionic radius of the B site ions $\left(\mathrm{Fe}^{3+}\right)$ as $\mathrm{G} / \mathrm{N}$ ratio increases, due to varying degrees of oxygen vacancies and hence mean transition metal oxidation state.

\subsection{Morphological study}

The morphology of particles in ceramic materials is a consequence of the preparation method, and combustion method favors obtaining porous nanoparticles, because the reactions produce homogeneous materials composed of small and uniform particles [26].

Representative SEM micrographs of the powder samples synthesised by the glycine nitrate combustion method at different conditions are shown in Fig. 3. These powders are composed of nanosized particles which agglomerate into grains.

Figure 3

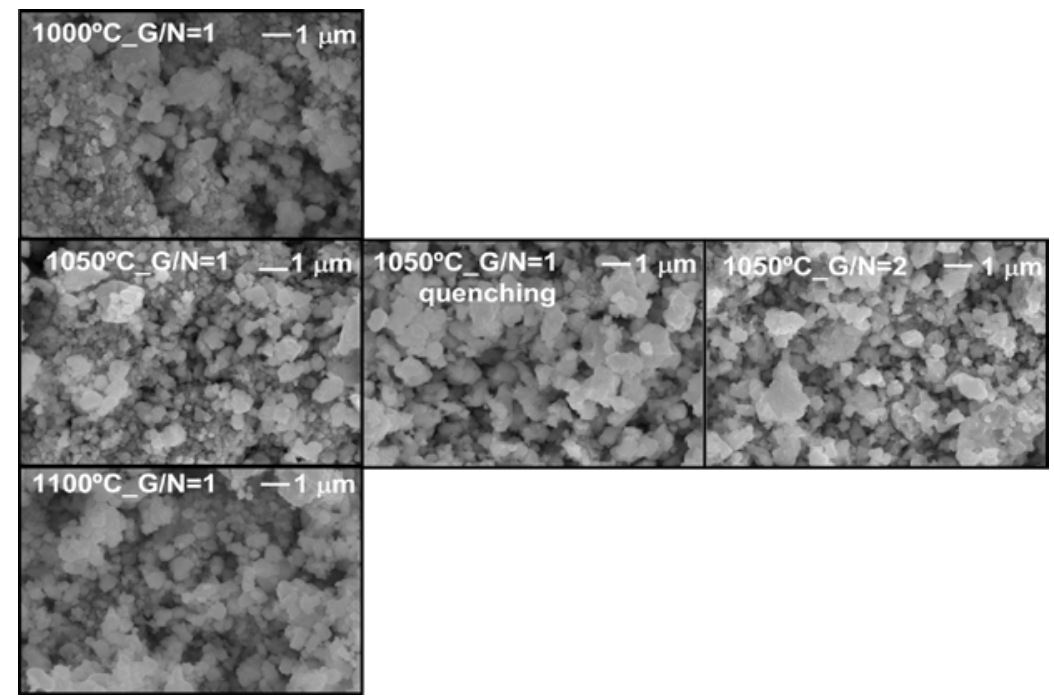

Fig. 3. Micrographs of $\mathrm{La}_{0.15} \mathrm{Sm}_{0.35} \mathrm{Sr}_{0.08} \mathrm{Ba}_{0.42} \mathrm{FeO}_{3-\delta}$ perovskites obtained at different synthetic conditions. 
The surface areas of the powders have been calculated using the Brunauer-EmmettTeller nitrogen adsorption (BET) method [18]. BET specific surface area values for the obtained powders are shown in Table 5.

Table 5

Table 5. BET specific surface areas of the powder samples.

\begin{tabular}{c|c|c}
\hline Tsynthesis $\left({ }^{\circ} \mathrm{C}\right)$ & $\mathrm{G} / \mathrm{N}$ & $\mathrm{S}_{\mathrm{BET}}\left(\mathrm{m}^{2} / \mathrm{g}\right)$ \\
\hline 1000 & 1 & 2.81 \\
\hline 1050 & 1 & 2.11 \\
\hline 1050 with quenching & 1 & 1.72 \\
\hline 1050 & 2 & 1.99 \\
\hline 1100 & 1 & 1.56 \\
\hline
\end{tabular}

As expected, the specific BET surface area of the samples decreases as calcination temperature increases. For the samples obtained at the same temperature $\left(1050^{\circ} \mathrm{C}\right)$ there is a slight decrease in specific surface area by increasing the cooling rate or the $\mathrm{G} / \mathrm{N}$ molar ratio.

On the other hand, SEM micrographs taken on the surface of the bars sintered at the same temperature $\left(1250^{\circ} \mathrm{C}\right)$ are shown in Fig. 4.

Figure 4 


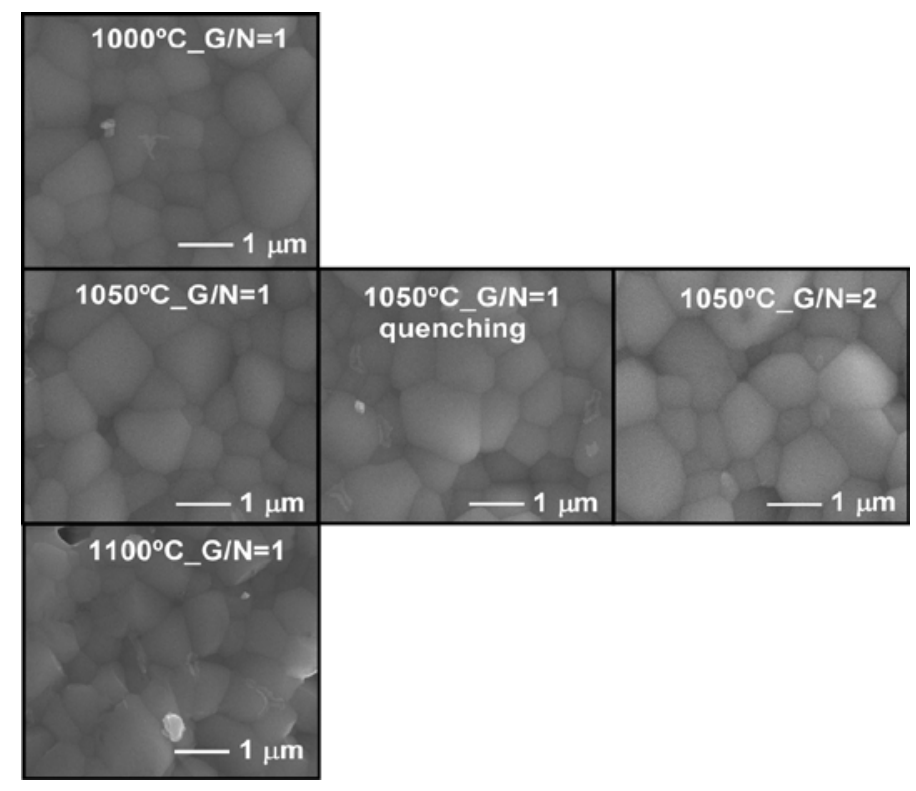

Fig. 4. SEM micrographs taken on the surface of the $\mathrm{La}_{0.15} \mathrm{Sm}_{0.35} \mathrm{Sr}_{0.08} \mathrm{Ba}_{0.42} \mathrm{FeO}_{3-\delta}$ pellets sintered at $1250^{\circ} \mathrm{C}$.

These measurements show that grain size slightly increases from $0.84 \mu \mathrm{m}$, in the sample obtained at $1000^{\circ} \mathrm{C}$, up to $0.92 \mu \mathrm{m}$ in that prepared at $1100^{\circ} \mathrm{C}$. The higher calcination temperature explains satisfactorily the larger grain size observed for this sample $[27,28]$.

For a particular synthetic method, the experimental conditions (calcination temperature, fuel/oxidizer ratio, cooling rate, etc...) play an important role in the power sinterability, and then, on the overall electrical properties of the electrolyte and electrode materials $[25,29,30]$. Usually, smaller particle size is beneficial to sintering and results in higher density when the sintering process is complete. This effect has been observed, obtaining a relative density of 87,88 and $83 \%$ for the samples calcined at 1000,1050 and $1100^{\circ} \mathrm{C}$, respectively. The relative density value obtained for both samples prepared at $1050^{\circ} \mathrm{C}$ under different conditions (with quenching and $\mathrm{G} / \mathrm{N}=2$ ) was $83 \%$ of the theoretical. Those results are consistent with SEM and BET experiments 


\subsection{Electrical conductivity study}

The total electrical conductivity as a function of temperature measured by the fourpoint method for the studied samples is shown in Fig. 5. The values of the conductivity were corrected to account for the porosity of the samples using equations 1 and 2 [31]:

$$
\begin{aligned}
& \sigma_{\text {corrected }}=\sigma_{\text {measured }}\left(1+\frac{P_{\text {fvol }}}{1-\left(P_{\text {fvol }}\right)^{2 / 3}}\right) \\
& P_{\text {fvol }}=1-\left(\rho_{\text {exp }} / \rho_{\text {theor }}\right)
\end{aligned}
$$

where $\rho_{\exp }$ is the experimental geometric density of a pelletised sample and $\rho_{\text {theor }}$ the theoretical density from XRD measurements. Note that the relative density, ( $\left.\rho_{\exp } / \rho_{\text {theor }}\right)$, could be slightly underestimated because the formula weight used in the $\rho_{\text {theor }}$ calculation ignores oxygen vacancies.

Figure 5
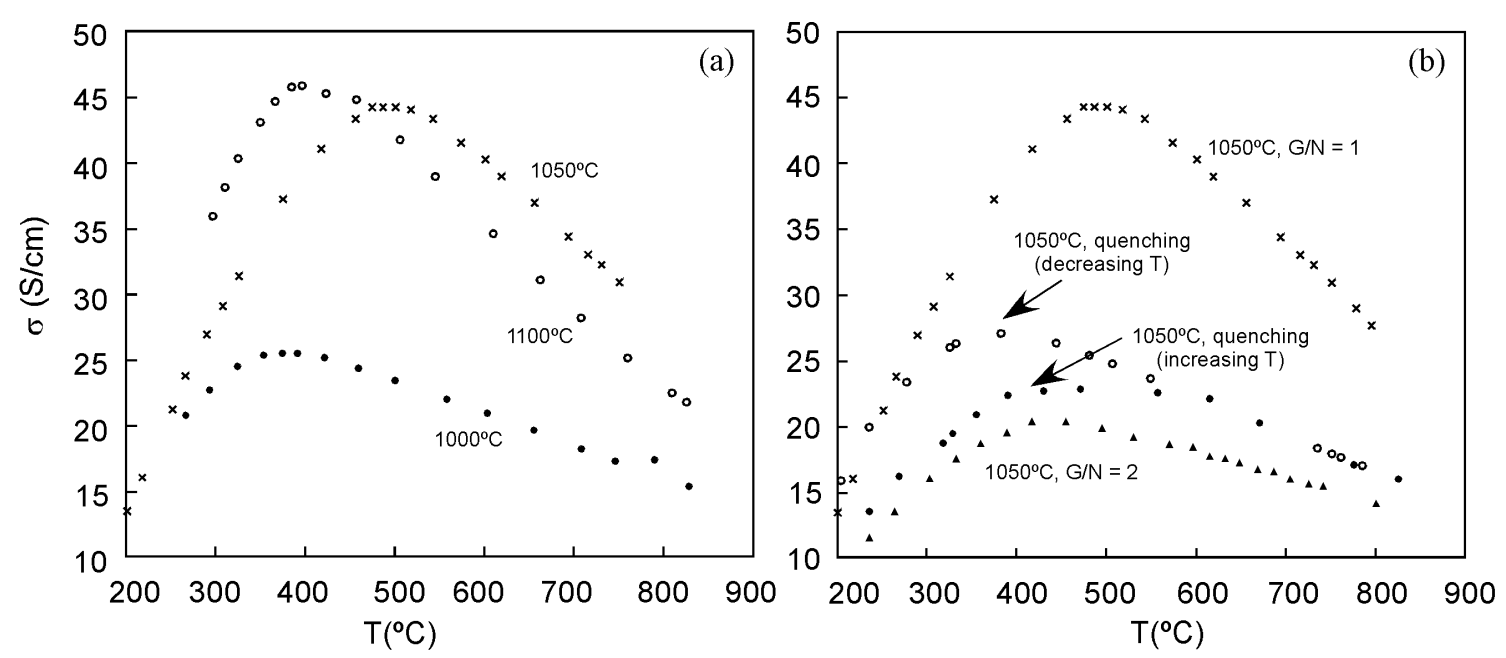

Fig. 5. Conductivity dependence upon temperature for the perovskites sintered by glycine nitrate combustion method (a) with $\mathrm{G} / \mathrm{N}=1$ obtained at different calcination temperature and (b) obtained at $1050^{\circ} \mathrm{C}$ using different preparation conditions. 
Electrical conductivity in Sr-doped $\mathrm{LaFeO}_{3}$ is generally believed to occur by the hopping of p-type small polarons [32], associated with the tetravalent state of the iron cations. It is well known that the electron transport in these compounds occurs via the electron holes of the $\mathrm{Fe}^{4+}-\mathrm{O}^{2-}-\mathrm{Fe}^{3+}$ chains, which also implies that a distortion of the migration pathway (Fe-O-Fe bond angle $180^{\circ}$ ) leads to a decrease in the mobility of the electron carriers [33]. The reduction of the conductivity at higher temperatures is due to the formation of oxygen vacancies, accompanied by reduction of $\mathrm{Fe}^{4+}$ to $\mathrm{Fe}^{3+}$ that results in a reduction of the charge carrier concentration [34].

As expected, the sample obtained at lowest temperature, shows the smaller value of conductivity in comparison with the other two compounds calcined at higher temperature. At temperatures below approximately $450^{\circ} \mathrm{C}$, the highest electrical conductivity is observed for the sample obtained at $1100^{\circ} \mathrm{C}$, and above this temperatures became higher for the calcined at $1050^{\circ} \mathrm{C}$.

The preparation route has an important influence on the electrical properties of the obtained materials. At the same calcination temperature, the material obtained with $\mathrm{G} / \mathrm{N}$ $=1.0$ and slow cooling rate shows the higher conductivity. An important hysteresis in the temperature dependence of the conductivity was observed for the quenched sample, being the conductivity on cooling down higher than that on heating up, possibly due to a rearrangement of oxygen vacancies??.

The electrical conductivity values obtained at 700 and $800^{\circ} \mathrm{C}$ for all the compounds are given in Table 6 . 
Table 6. Electrical conductivity values of $\mathrm{La}_{0.15} \mathrm{Sm}_{0.35} \mathrm{Sr}_{0.08} \mathrm{Ba}_{0.42} \mathrm{FeO}_{3-\delta}$ perovskites at 700 and $800^{\circ} \mathrm{C}$.

\begin{tabular}{c|c|c}
\hline $\begin{array}{c}\text { Preparation } \\
\text { conditions }\end{array}$ & $\sigma_{\left(\mathbf{7 0 0}{ }^{\circ} \mathrm{C}\right)}(\mathrm{S} / \mathbf{c m})$ & $\left.\sigma_{(\mathbf{8 0 0}}{ }^{\circ} \mathrm{C}\right)$ \\
\hline $\left.1000^{\circ} \mathrm{C}, \mathrm{cm}\right)$ \\
\hline $1050^{\circ} \mathrm{C}, \mathrm{N} / \mathrm{N}=1$ & 18.50 & 16.03 \\
\hline $\begin{array}{c}1050^{\circ} \mathrm{C}, \mathrm{G} / \mathrm{N}=1, \text { quenching } \\
\text { (increasing T) }\end{array}$ & 34.04 & 27.45 \\
\hline $\begin{array}{c}1050^{\circ} \mathrm{C}, \mathrm{G} / \mathrm{N}=1, \text { quenching } \\
\text { (decreasing T) }\end{array}$ & 19.47 & 16.56 \\
\hline $1050^{\circ} \mathrm{C}, \mathrm{G} / \mathrm{N}=2$ & 16.47 & 16.68 \\
\hline $1100^{\circ} \mathrm{C}, \mathrm{G} / \mathrm{N}=1$ & 29.05 & 14.21 \\
\hline
\end{tabular}

At 700 and $800{ }^{\circ} \mathrm{C}$, typical operating temperatures for the application of these materials in SOFC technology, the conductivity for the sample obtained at $1050^{\circ} \mathrm{C}$ with GN = 1 and slowly cooled, shows the highest value of electrical conductivity.

\subsection{Catalytic oxidation of CO}

All the prepared perovskites presented a very similar catalytic behaviour. Fig. 6 shows the light-off curve (percentage of CO converted vs. temperature) recorded for the perovskite prepared at $1050^{\circ} \mathrm{C}$ with $\mathrm{G} / \mathrm{N}=1$, which is representative of all the set of samples. A value of light-off temperature $\left(\mathrm{T}_{50} \%\right)$ about $450^{\circ} \mathrm{C}$ (Table 7$)$ is observed. Note also that $100 \% \mathrm{CO}$ combustion takes place at approximately $600^{\circ} \mathrm{C}$. As indicated in Table 7, all the samples presented similar conversion values (T50\%), these being in good agreement with previous studies on related perovskite systems [35]. 


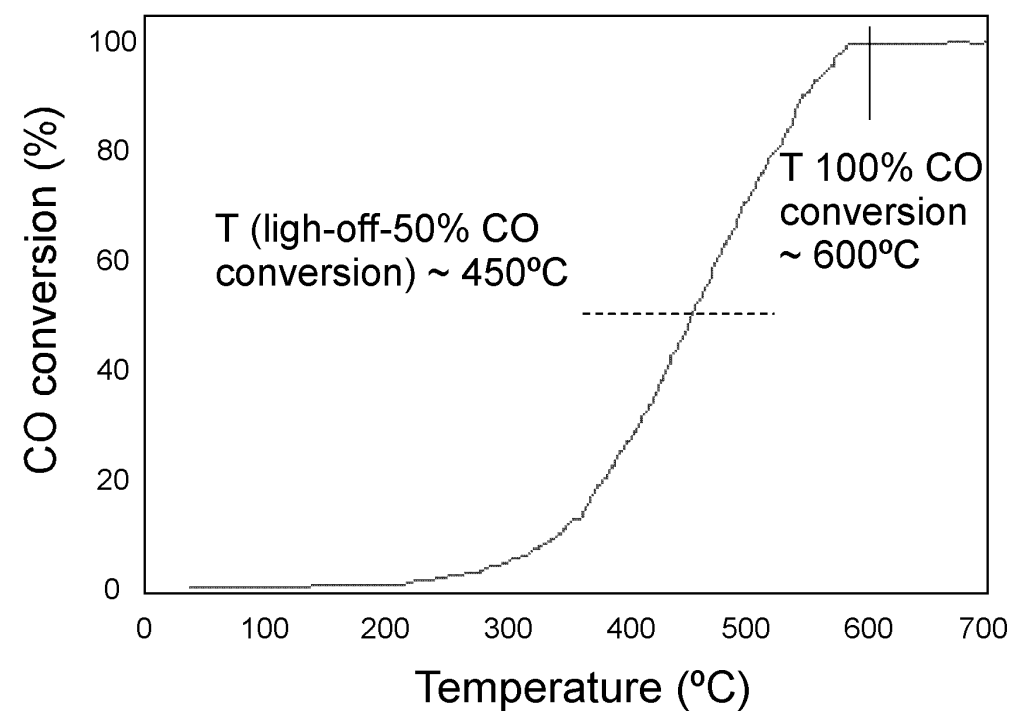

Fig. 6. CO oxidation as a function of temperature for the $\mathrm{La}_{0.15} \mathrm{Sm}_{0.35} \mathrm{Sr}_{0.08} \mathrm{Ba}_{0.42} \mathrm{FeO}_{3-\delta}$ perovskite obtained at $1050^{\circ} \mathrm{C}$ with stoichiometric $\mathrm{G} / \mathrm{N}$ value.

Table 7. Light of Temperature (T50\%) in ${ }^{\circ} \mathrm{C}$

\begin{tabular}{c|c|c}
\hline Tsynthesis $\left({ }^{\circ} \mathbf{C}\right)$ & G/N & T50\% $\left({ }^{\circ} \mathbf{C}\right)$ \\
\hline 1000 & 1 & 442 \\
\hline 1050 & 1 & 440 \\
\hline 1050 with quenching & 1 & 442 \\
\hline 1050 & 2 & 449 \\
\hline 1100 & 1 & 448 \\
\hline
\end{tabular}

According to structural studies, the perovskites calcined at high temperature have lower oxygen content. Oxygen vacancies may contribute to increase oxygen mobility, a factor that could improve CO oxidation activity in case of an intrafacial type mechanism [36]. Since the catalytic activity is the same for all the studied perovskites, it seems that the reaction proceeds, instead, by a suprafacial mechanism. In this alternative reaction path, chemisorbed oxygen species react with CO on the perovskite surface, without participation of oxygen from the solid [37]. 
Although the activity of the prepared perovskite catalyst in CO oxidation is lower than that of conventional catalyst made of noble metal (Pt, Pd) [38], they exhibit advantages to these, apart from the absence in the formulation of expensive and critical elements, like a much higher sulphur tolerance[39]. Additionally, it is important to stress that the CO full conversion temperatures determined for all the synthesized perovskites is lower than the usual SOFCs operating temperatures, which clearly points out to their potential application in these technologies.

\section{Conclusions}

Five $\mathrm{La}_{0.15} \mathrm{Sm}_{0.35} \mathrm{Sr}_{0.08} \mathrm{Ba}_{0.42} \mathrm{FeO}_{3-\delta}$ compounds have been obtained by glycine nitrate method varying the calcination temperature, fuel/oxidizer ratio and cooling rate, in order to study the effect on the structural, morphological, catalytic and electrical properties. At room temperature, all compounds present rhombohedral symmetry (S.G.: R-3c). A well-necked morphology of the powders, which are composed of nanosized particles and agglomerations of grains, has been obtained in good agreement with the BET specific surface areas of the samples that decreases as calcination temperature increases. Catalytic oxidation tests for the samples achieved 100\% CO combustion at about $600^{\circ} \mathrm{C}$. On the other hand, it has been observed that the electrical conductivity is dependent on synthetic conditions, the material obtained with $\mathrm{G} / \mathrm{N}=1.0$ showing higher conductivity. So, this material is expected to show good properties for cathode in oxide fuel cells and catalyst in vehicle engines due to its higher electrical conductivity and CO oxidation obtained values. These results confirm the important role that the variation of synthetic conditions plays on the properties of perovskite type materials.

\section{Acknowledgements}


This research has been funded by the Ministerio de Ciencia e Innovación

(CONSOLIDER-INGENIO 2010 CSD2009-00013), Ministerio de Economía y

Competitividad (MAT2013-42092-R and MAT2012-30763) and Dpto. Educación,

Política Lingüística y Cultura of the Basque Goverment (IT-630-13). The authors thank

SGIker (UPV/EHU) technical support. K. Vidal thanks UPV/EHU for funding.

\section{References}

[1] Chesnokov KY, Markov AA, Patrakeev MV, Leonidova IA, Murzakaev AM, Leonidova ON, Shalaeva EV, Kharton VV, Kozhevnikov VL. Structure and transport properties of $\mathrm{La}_{0.5} \mathrm{Sr}_{0.5-\mathrm{x}} \mathrm{Ca}_{x} \mathrm{FeO}_{3-\delta}$. Solid State Ionics 2014; 262: 672-677.

[2] Morán-Ruiz A, Vidal K, Larrañaga A, Porras-Vázquez JM, Slater PR, Arriortua MI. Evaluation of using protective/conductive coating on Fe-22Cr mesh as a composite cathode contact material for intermediate solid oxide fuel cells. Int J Hydrogen Energ 2015;40: 4804-4818.

[3] Keav S, Matam SK, Ferri D, Weidenkaff A. Structured perovskite-based catalyst and their application as three way catalytic converters. A review. Catalyts 2014;4:226-255.

[4] Venkataswamy P, Rao KN, Jampaiah D, Reddy BM. Nanostructured manganese doped ceria solid solutions for CO oxidation at lower temperatures. Appl Catal B 2015;162:122-132.

[5] Xiao P, Zhu J, Li H, Jiang W, Wang T, Zhu Y, Zhao Y, Li J. Effect of textural structure on the catalytic performance of $\mathrm{LaCoO}_{3}$ for $\mathrm{CO}$ oxidation. ChemCatChem 2014;6:1774-1781.

[6] Huang S, Hara K, Fukuoka A. Green catalysis for selective CO oxidation in hydrogen for fuel cell. Energ Environ Sci 2009;2:1060-1068.

[7] Ammal SC, Heyden A. Reaction kinetics of the electrochemical oxidation of CO and syngas fuels on a $\mathrm{Sr}_{2} \mathrm{Fe}_{1.5} \mathrm{Mo}_{0.5} \mathrm{O}_{6-\delta}$ perovskite anode. J Mater Chem A 2015;3:21618-21629.

[8] Sun C, Hui R, Roller J. Cathode materials for solid oxide fuel cells: a review. J Solid State Electrochem 2010;14:1125-1144.

[9] Xiao P, Zhong L, Zhu J, Hong J, Li J, Li H, Zhu Y. CO and soot oxidation over macroporous perovskite $\mathrm{LaFeO}_{3}$. Catal Today 2015;258:660-667.

[10] Islam QA, Raja MW, Basu RN. Synthesis of $\mathrm{BaBi}_{0.2} \mathrm{Co}_{0.35} \mathrm{Fe}_{0.45} \mathrm{O}_{3-\delta}$ by a novel aqueous soft chemical method and its characterizations. J Alloy Compd 2014;583:714.

[11] Vidal K, Morán-Ruiz A, Larrañaga A, Porras-Vázquez JM, Slater PR, Arriortua MI. Characterization of $\mathrm{LaNi}_{0.6} \mathrm{Fe}_{0.4} \mathrm{O}_{3}$ perovskite synthesized by glycine-nitrate combustion method. Solid State Ionics 2015; 269:24-29.

[12] Zhu C, Nobuta A, Nakatsugawa I, Akiyama T. Solution combustion synthesis of $\mathrm{LaMO}_{3}(\mathrm{M}=\mathrm{Fe}, \mathrm{Co}, \mathrm{Mn})$ perovskite nanoparticles and the measurement of their electrocatalytic properties for air cathode. Int J Hydrogen Energ 2013;38: 13238- 
13248.

[13] Rodríguez-Martínez M, Attfield JP. Cation disorder and size effects in magnetoresistive manganese oxide perovskites. Phys Rev B 1996;54: R15622R15625.

[14] Vidal K, Rodríguez-Martínez LM, Ortega-San-Martín L, Nó ML, Rojo T, Arriortua MI. Effect of the A cation size disorder on the properties of an iron perovskite series for their use as cathodes for SOFCs. Fuel Cells 2011;11:51-58.

[15] Ecija A, Vidal K, Larrañaga A, Martínez-Amesti A, Ortega-San-Martín L, Arriortua MI. Structure and properties of perovskites for SOFC cathodes as a function of the A-site cation size disorder. Solid State Ionics 2013; 235:14-21.

[16] Rodrıuez-Carvajal J. FULLPROF rietveld pattern matching analysis of powder patterns, Grenoble. 2011.

[17] Larson AC, Von Dreele RB. GSAS: General Structure Analysis System, LAUR, 1994.

[18] Brunauer S, Emmett PH, Teller E. Adsorption of gases in multimolecular layers. J Am Chem Soc 1938; 60:309-319.

[19] Lay E, Benamira M, Pirovano C, Gauthier G, Dessemond L. Effect of Ce-doping on the electrical and electrocatalytical behavior of La/Sr chromo-manganite perovskite as new SOFC anode. Fuel Cells 2012;12(2):265-274.

[20] Sun Y, Yan N, Li J, Wu H, Luo JL, Chuang KT. The effect of calcination temperature on the electrochemical properties of $\mathrm{La}_{0.3} \mathrm{Sr}_{0.7} \mathrm{Fe}_{0.7} \mathrm{Cr}_{0.3} \mathrm{O}_{3-\mathrm{x}}$ (LSFC) perovskite oxide anode of solid oxide fuel cells (SOFCs). Sustain Energy Technol Assess 2014;8:9298.

[21] Shannon RD. Revised effective ionic radii and systematic studies of interatomic distances in halides and chaleogenides. Acta Cryst 1976;A32:751-767.

[22] Zhou XD, Cai Q, Yang J, Yelon WB, James WJ, Anderson HU. Utilization of neutron diffraction and Mössbauer spectroscopy in the studies of the cathode for SOFCs. Solid State Ionics 2004;175:83-86.

[23] Ge L, Zhu Z, Shao Z, Wang S, Liu S. Effects of preparation methods on the oxygen nonstoichiometry, B-site cation valences and catalytic efficiency of perovskite $\mathrm{La}_{0.6} \mathrm{Sr}_{0.4} \mathrm{Co}_{0.2} \mathrm{Fe}_{0.8} \mathrm{O}_{3-\delta}$. Ceram Inter 2009;35:3201-3206.

[24] Deganello F, Marcí G, Deganello G. Citrate-nitrate auto-combustion synthesis of perovskite-type nanopowders: A systematic approach. J. Eur Ceram Soc 2009;29;439-450.

[25] Vidal K, Morán-Ruiz A, Larrañaga A, Porras-Vázquez JM, Slater PR, Arriortua MI. Characterization of $\mathrm{LaNi}_{0.6} \mathrm{Fe}_{0.4} \mathrm{O}_{3}$ perovskite synthesized by glycine-nitrate combustion method. Solid State Ionics 2015;269:24-29.

[26] da Conceição L, Silva AM, Ribeiro JNFP, Souza MMVM. Combustion synthesis of $\mathrm{La}_{0.7} \mathrm{Sr}_{0.3} \mathrm{Co}_{0.5} \mathrm{Fe}_{0.5} \mathrm{O}_{3}$ (LSCF) porous materials for application as cathode in ITSOFC. Mater Res Bull 2011;46(2):308-314.

[27] Melo Jorge ME, Correia dos Santos A, Nunes MR. Effects of synthesis method on stoichiometry, structure and electrical conductivity of $\mathrm{CaMnO}_{3-\delta}$. Inter J Inorg Mater 2001;3:915-921.

[28] Li S, Lu Z, Huang X, Wei B, Su W. Thermal, electrical, and electrochemical properties of lanthanum-doped $\mathrm{Ba}_{0.5} \mathrm{Sr}_{0.5} \mathrm{Co}_{0.8} \mathrm{Fe}_{0.2} \mathrm{O}_{3-\delta}$. J Physics Chem Solids 2007; 68:1707-1712.

[29] Deganello F, Marcí G, Deganello G. Citrate-nitrate auto-combustion synthesis of perovskite-type nanopowders: A systematic approach. J Eur Ceram Soc 2009; 29:439-450.

[30] Zhu C, Nobuta A, Nakatsugawa I, Akiyama T. Solution combustion synthesis of 
$\mathrm{LaMO}_{3}(\mathrm{M}=\mathrm{Fe}, \mathrm{Co}, \mathrm{Mn})$ perovskite nanoparticles and the measurement of their electrocatalytic properties for air cathode. Int J Hydrogen Energ 2013:12238-13248.

[31] Tripathi AK, Lal HB. Electrical transport in light rare-earth orthochromites. J Mate. Science 1982;17;1595-1609.

[32] Tai L-W, Nasrallah MM, Anderson HU, Sparlin DM, Sehlin SR. Structure and electrical properties of $\mathrm{La}_{1-\mathrm{x}} \mathrm{Sr}_{\mathrm{x}} \mathrm{Co}_{1-\mathrm{y}} \mathrm{Fe}_{\mathrm{y}} \mathrm{O}_{3}$. Part 1 . The system $\mathrm{La}_{0.8} \mathrm{Sr}_{0.2} \mathrm{Co}_{1-\mathrm{y}} \mathrm{Fe}_{\mathrm{y}} \mathrm{O}_{3}$. Solid State Ionics 1995;76: 259-271.

[33] Patrakeev MV, Leonidov IA, Kozhevnikov VL, Poeppelmeier KR. p-type electron transport in $\mathrm{La}_{1-\mathrm{x}} \mathrm{Sr}_{\mathrm{x}} \mathrm{FeO}_{3-\delta}$ at high temperatures. J Solid State Chem 2005;178: 921927.

[34] Brinks HW, Fjellvag H, Kjekshus A, Hauback BC. Structure and magnetism of Pr1${ }_{x} \mathrm{Sr}_{\mathrm{x}} \mathrm{FeO}_{3-\delta}$. J Solid State Chem 2000;150: 233-249.

[35] Zheng S, Hua Q, Gu W, B Liu. Catalytic oxidation of CO on $\mathrm{LaMn}_{1-\mathrm{x}} \mathrm{Fe}_{\mathrm{x}} \mathrm{O}_{3}$ perovskites solid solution. J Mol Catal A-Chem 2014;391:7-11.

[36] Yamazoe N, Teraoka Y. Oxidation catalysis of perovskites-relationships to bulk structure and composition. Catal Today 1990;8:175-199.

[37] Yang W, Zhang R, Chen B, Bion N, Duprez D, Royer S. Activity of perovskitetype mixed oxides for the low-temperature CO oxidation: Evidence of oxygen species participation from the solid. J Catal 2012;295:45-48.

[38] Malamis SA, Harrington RJ, Katz MB, Bion N, Koerschner DS, Zhang S, Cheng Y, Xu L, Jen HW, McCabe RW, Graham GW, Pan X. Comparison of precious metal doped and impregnated perovskite oxides for TWC application. Catal Today 2015;258:535-542.

[39] Matsuzaki Y, Yasuda I. The poisoning effect of sulfur-containing impurity gas on a SOFC anode: Part I. Dependence on temperature, time, and impurity concentration. Solid State Ionics 2000;132:261-269. 